\title{
Impact of JIT on inventory to sales ratios
}

By: Timonthy B. Biggart and Vidyaranya B. Gargeya.

Biggart, T. and Gargeya, V. B. (2002). Impact of JIT on inventory to sales ratios. Industrial Management \& Data Systems, 102(4): 197-202.

Made available courtesy of Emerald Group Publishing Limited: http://dx.doi.org/10.1108/02635570210423235

***;) Emerald Group Publishing Limited. Reprinted with permission. No further reproduction is authorized without written permission from Emerald Group Publishing Limited. This version of the document is not the version of record. Figures and/or pictures may be missing from this format of the document. $* * *$

This article is (c) Emerald Group Publishing and permission has been granted for this version to appear here (https://libres.uncg.edu/ir/uncg/). Emerald does not grant permission for this article to be further copied/distributed or hosted elsewhere without the express permission from Emerald Group Publishing Limited.

\section{Abstract:}

Just-In-Time (JIT) production has received a great deal of attention, worldwide, since its introduction in Japan a few decades ago. It has been well documented that some of the main benefits of JIT implementation are reduction of inventories, lead-time reduction, and cost savings. Most of the previous research on the impact of JIT on firm performance has either been anecdotal (one-firm studies), or cross-sectional (comparing JIT firms with non-JIT firms at one point in time) in nature. This paper focuses on studying the impact of JIT on inventories to sales ratios prior- and post-adoption based on actual performance of 74 firms as reported in COMPUSTAT data. Results show that the total inventory to sales ratio and raw material inventory to sales ratio decreased post-implementation; however, there has not been any statistically significant change in work-in-process inventory to sales ratio and finished goods inventory to sales ratio post-implementation.

Keywords: Just-in-time | Inventory | Sales | Inventory turnover | Benefits

\section{Article:}

The just-in-time (JIT) production system (as the Toyota Production System) was introduced by Shigeo Shingo and Taichi Ohno, at the Toyota Motor plant in the mid-1970s. JIT production is called by many names: Zero Inventory Production System (ZIPS), Minimum Inventory Production System (MIPS), Kanban production, Kaizen production, Stockless production, Pullthrough production, and Quick Response (QR) Inventory Systems. JIT manufacturing, both as a philosophy and a disciplined method of production, has received much attention since its introduction. The JIT production philosophy is founded upon three fundamental principles: elimination of waste, continuous quality improvement, and encouragement of worker 
participation in operations planning and execution (Harber et al., 1990). Firms implementing JIT seek to minimize the need for raw materials, work-in-process (WIP) and finished goods inventory by focusing on the reducing set up times, coordinating of JIT deliveries from suppliers with production needs, balancing productive capacities of internal processes, and, above all, maintaining a continuing commitment to achieving the highest level of quality at all stages of the business transaction. The overall goal of JIT is to eliminate waste, where waste is defined as anything that does not specifically add value to the product or service. As such, JIT can be viewed as a long-term strategy, one that promotes excellence and eliminates waste throughout the company. JIT is a continuous process, and instituting a JIT program in an organization has been described as a "race without a finish". Rather, success in implementing JIT can be viewed in terms of the extent to which the culture and philosophy of JIT permeates the organization and the degree of commitment (to the JIT principles) that the managers demonstrate. In fact, this philosophy is now being applied to service sector companies without physical inventories (Canel et al., 2000).

The feasibility of implementing JIT systems in any kind of an environment can be fully understood by addressing the elements of JIT production and relating each of them to the others. Some of the more frequently identified elements of the JIT production strategy include the education and training (including cross-training) of employees in the JIT philosophy, setup time reduction, cellular manufacturing/group technology $(\mathrm{CM})$, continuous quality improvement (CQI), and supplier partnerships (Ebrahimpour and Schonberger, 1984; Gargeya and Thompson, 1994; Sohal et al., 1993). The reduction in setup time, and achieving CQI also leads to elimination of waste (in terms of equipment downtime, scrap, and rework). Variance can be reduced through the application of CM, and CQI, and the development of long-term supplier partnerships. An organization that eliminates waste, and reduces variance on a continuing basis improves its shop performance through reduction in lead-time, WIP, and operating expenses, and throughput increases leading to excellence and growth. It is acknowledged that other intermediary benefits from JIT implementation do exist in the form of increased teamwork, higher worker motivation, increased equipment and worker efficiency, and increased productivity (Schonberger, 1986). These intermediary benefits, however, do translate into elimination of waste, variance reduction, and overall enhancement of shop performance.

The current paper focuses on the extent to which the implementation of JIT has affected total inventory to sales (TIS), raw material inventory to sales (RMIS), WIP inventory to sales (WIPIS), and finished goods inventory to sales (FGIS) ratios. The next section presents a brief review of the literature, followed by a section describing the hypotheses in this research. Then the research methodology is presented followed by a section on the results and conclusions.

\section{Review of the literature}

A review of the literature indicates that there is an enormous amount of empirical work that has been done on the implementation of JIT and its benefits (Billesbach, 1991; Chin and Rafuse, 1993; Cook and Rogowski, 1996; Crawford et al., 1988; Deshpande and Golhar, 1995; Golhar et al., 1990; Handfield, 1993; Hobbs, 1994; Howton et al., 2000; Im and Lee, 1989; Inman and Mehra, 1993; Payne, 1993; Pelagagge, 1997; Sohal et al., 1993; Sriparavastu and Gupta, 1997; Stamm and Golhar, 1991; Temponi and Pandya, 1995; White, 1993; White et al., 1999; Yasin et 
al., 1997). Most of the research (whether case based or survey based) done thus far on the benefits of the adoption of JIT production mechanisms has either been anecdotal (Chin and Rafuse, 1993; Cook and Rogowski, 1996), or cross-sectional, i.e. comparing JIT firms with nonJIT firms at one point in time (Inman and Mehra, 1990; Lawrence and Hottenstein, 1995; and Sriparavastu and Gupta, 1997), or confined to a single firm (Pelagagge, 1997). The multiple-firm empirical studies (Crawford et al., 1988; Golhar et al., 1990; White, 1993; White et al., 1999; Yasin et al., 1997) have only sought the perceptual opinion of one individual in the organization on the benefits accrued.

Vergin (1998) conducted a longitudinal study by analyzing the changes in the inventory turnover ratio of 427 firms from the Fortune 500 list of the largest corporations in the USA, during the 1986 to 1995 period, using regression analysis. His results showed that the slope of the regression model was different from zero at a statistically significant level of 0.0001 . However, he did not classify the firms based on whether the firms were JIT adopters or not.

Howton et al. (2000) examined the reaction of financial markets and financial analysts to JIT adoption. They found that for 97 JIT adopters, there was a significant, positive stock market reaction at the time of announcement. However, financial analysts did not significantly increase their one- three or five-year forecasts of earnings for those companies.

There have been only three studies (Balakrishnan et al., 1996; Billesbach and Hayen, 1994; Huson and Nanda, 1995) that have used longitudinal data to study the benefits of JIT implementation on firm performance. Balakrishnan et al. (1996) studied a sample of 46 firms that publicly disclosed adopting JIT production during a very narrow time frame of 1985 to 1989, against a sample of 46 firms in a control group that did not adopt JIT production systems. The 46 firms that adopted JIT practices were predominantly from eight different industries (furniture and fixtures, rubber products, primary metal, fabricated metal, industrial machinery, electronics, motor vehicles and accessories, and instrumentation) using a two-digit Standard Industrial Code (SIC). In terms of assets, the 46 JIT adoption firms averaged $\$ 330.80$ million (with a median of $\$ 85.13$ million). In terms of net sales, the sample averaged $\$ 378.27$ million (with a median of $\$ 108.50$ million). Their results showed that there was statistically significant difference (at a $p$ value less than 0.01 ) in the overall inventory turnover ratio, raw material turnover ratio, and WIP turnover ratio pre- and post-JIT adoption. The difference in the pre- and post-JIT adoption finished goods turnover ratio was not statistically significant at the 0.01 level.

Billesbach and Hayen (1994) compared the average sales to total inventory ratio during the 1977-1979 period of 28 firms that had adopted JIT practices to the average sales to total inventory ratio during the 1987-1989 period of those 28 firms. Unlike the study reported by Balakrishnan et al. (1996), Billesbach and Hayen (1994) only considered total inventory and not raw material, WIP, and finished goods. Their results showed an increase in the average sales to inventory ratio for 25 out of the 28 firms at a $p$-value less than 0.05 .

Research by Huson and Nanda (1995) focused on the average inventory turnover ratio four years pre- and post-JIT adoption of 55 firms (in 15 different industries representing four one-digit SIC codes). The firms had adopted JIT production methods during the 1980-1990 period. Similar to the work by Billesbach and Hayen (1994), Huson and Nanda (1995) considered only total 
inventory not raw material, WIP, and finished goods. Their results showed a statistically significant (at a $p$ value of 0.01 ) increase in the average inventory turnover ratio. The findings of Balakrishnan et al. (1996) are noteworthy. However, their results are based on 46 firms (from only two one-digit SIC codes) that have adopted JIT production systems during a narrow (fouryear) time span. The studies by Billesbach and Hayen (1994) and Huson and Nanda (1995) span a longer time horizon as well as include firms from a wider range of industries; however, both sets of researchers have considered inventory in a composite form.

\section{Research hypotheses}

The literature review and the earlier discussion on JIT production systems give rise to the following set of research hypotheses about the benefits of implementing JIT production based on a study of firms from a wide variety of industries:

H1. Firms that have adopted JIT production will have a decreased level of inventory to sales ratio post adoption.

H2. Firms that have adopted JIT production will have a decreased level of raw material inventory to sales ratio post adoption.

H3. Firms that have adopted JIT production will have a decreased level of WIP inventory to sales ratio post adoption.

H4. Firms that have adopted JIT production will have a decreased level of finished goods inventory to sales ratio post adoption.

\section{Research methodology}

The method used in this research is analysis of data from secondary sources. An attempt was made to identify all firms (within the USA) that made public announcements of JIT adoption during the period 1975 to 1995 . We used Mead Data's Lexis/Nexis electronic database (hereafter, Lexis) and the Wall Street Journal Index (WSJI) to identify firms that publicly disclosed a JIT adoption. On the Lexis database, we searched three sets of files for the period: the PR newswire, the Major Newspaper files and the National Automated Accounting Retrieval System (NAARS) database. PR Newswire is one of the most common sources used by firms making press releases and when used in combination with the Major Newspaper files, it should provide a comprehensive basis for identifying publicly available information about large US companies. The Major Newspaper files contain an index of 44 worldwide papers, including such important US newspapers as the New York Times, Washington Post and Los Angeles Times.

Identification of JIT adoption is complicated by the lack of a common name for the elements that make up the JIT system. The JIT production system, in addition to being called by the acronym JIT, has been referred to as Zero Inventory Production System (ZIPS), Minimum Inventory Production System (MIPS), kanban production (the Japanese word for the sign cards used to control demand pull production), and kaizan production (the Japanese word used to refer to a continuous improvement philosophy). 
We searched the Lexis files for all these JIT synonyms, as well as JIT itself. This search pattern was repeated for the WSJI subject listing for the categories "inventory" and "inventory management". To the firms detected by these searches, we added the samples from previous JIT research by Moras and Dieck (1992) and Billesbach and Hayen (1994); every firm included in their samples was identified in our search of the Lexis database.

We took several steps to verify that the identified adoption announcement date was the earliest public association with JIT, addressing two potential announcement-related problems. The first was that an announcement might have appeared in the Wall Street Journal prior to the Lexis announcement, but the announcement did not appear in the WSJI subject listing under the categories "inventory" or "inventory management". In order to investigate this possibility, we examined all of the listings in the WSJIfor each firm in the sample from 1 January 1975, the beginning of the sample period, through that firm's Lexis JIT adoption announcement date. In no case did a firm have a WSJI adoption date earlier than the Lexis adoption date.

A second potential problem with regard to the announcement date was that a firm could announce the adoption of JIT without using any of the key-word patterns we used in our data searches. For the firms in our sample, we investigated this potential problem by reading all inventory-related disclosures on Lexis for each firm in the sample from the beginning of the sample period to the previously identified JIT adoption date. Any announcement that contained one or more of the key JIT system concepts (reduced machine setup times, employee empowerment in the production process, inventory reductions or changes in supplier relationships) was read by two raters to determine if the announcement was considered to be a JIT announcement. A few firms did in fact have such disclosures, and the announcement dates were changed to the prior disclosure.

The sample included 238 US firms for which public announcement of JIT adoption occurred between 1975 and 1995; none of the announcements occurred before 1980. Of these 238 firms, 164 firms were eliminated due to unavailability of total inventory data. The final sample included 74 firms. Data for a seven-year period (three years prior to JIT adoption and three years post JIT adoption) was collected. Year 4 was considered as the adoption year. The description of the sample by industry is provided in Table I.

Table I shows that 15 different industries (using a two-digit SIC) were represented in the sample. Based on the average number of employees $(65,552$ with a median value more than 25,000$)$, average total assets (about $\$ 6.7$ billion with a median value more than $\$ 2.7$ billion), and average net sales (about $\$ 8.3$ billion with a median value close to $\$ 3$ billion), it can be deduced that the sample represents large organizations. The sample in this study represents firms much larger than the ones in the study by Balakrishnan et al. (1996). In the current sample, only three firms had less than 1,000 employees, only four firms had less than $\$ 100$ million in assets, and only three firms had less than $\$ 100$ million in sales. In terms of number of employees, the smallest organization had 90 and the largest firm had 657,000. In terms of assets, the range between the smallest and the largest firms was $\$ 9$ million to $\$ 87.56$ billion. In terms of sales, the smallest organization had $\$ 14$ million and the largest had close to $\$ 103$ billion. 
The inventory change measures used in this study are the differences between the two-year average TIS, average RMIS, average WIPIS, and average FGIS ratios in years 1 and 2 and the two-year average TIS, average RMIS, average WIPIS, and average FGIS ratios in years 6 and 7 . The two-year average has been used to smooth out any temporary changes in inventory levels. We excluded the data of years 3,4 , and 5 in order to eliminate the co-mingling of pre-adoption and post-adoption measures. The use of TIS, RMIS, WIPIS, and FGIS (as opposed to actual inventories) allows for comparisons across different firm sizes. Scaling inventory by sales results in our study measuring relative changes in inventory levels. It should be noted that sales (as compared to total assets or market value of equity) is the standard for scaling in inventory studies, as well as the scaling factor used by the Department of Commerce in its inventory reporting. Then Analysis of Variance (ANOVA) was used for testing the hypothesis.

\section{Results and conclusions}

The findings indicate that the total inventory to sales ratio and the raw material inventory to sales ratio reduced substantially (at a statistical significance level of 0.01) post-JIT adoption. There has, however, been no statistically significant change (at the 0.01 level) in the WIP inventory to sales ratio and finished goods inventory to sales ratio post-JIT implementation (Table II). Except for the results with regard to WIP inventory to sales ratio, the findings are in consonance with those arrived at by Balakrishnan et al. (1996). The findings from the current study indicate that firms reduced their total inventory primarily through reductions in raw material inventory and not through significant reductions in WIP and finished goods inventories. This means that the firms were probably "wielding the stick" on their suppliers to reduce their own raw material inventories. The firms did not have the same success internal to their own organizations or with their customers. It should be noted (from Table I) that the sample predominantly consists of very large firms. These firms would have the capability to influence their suppliers, particularly if the latter are small companies, in making JIT deliveries. This would result in reducing the inventory of raw materials at the large manufacturer's/buyer's premises at the possible expense of increasing the inventories at the supplier's location. It would be interesting to study the impact of the adoption of JIT production by different firms on the inventory profiles of their suppliers, in particular, and across the supply network, in general. 


\begin{tabular}{|c|c|c|c|c|c|}
\hline $\begin{array}{l}\text { Standard } \\
\text { Industrial code }\end{array}$ & Industry description & Count & $\begin{array}{l}\text { Average number } \\
\text { of employees" }\end{array}$ & $\begin{array}{c}\text { Average total } \\
\text { assets (in \$ } \\
\text { millions) }\end{array}$ & $\begin{array}{c}\text { Average net } \\
\text { sales (in \$ } \\
\text { millions) }\end{array}$ \\
\hline 2000 & Food products & 2 & 42,363 & 4,511 & 5,536 \\
\hline 2300 & Apparel & 1 & 57,000 & 2,712 & 3,824 \\
\hline 2600 & Paper products & 2 & 48,290 & 5,699 & 6,785 \\
\hline 2700 & Printing & 1 & 4,228 & 397 & 565 \\
\hline 2800 & Chemicals & 6 & 26,639 & 4,522 & 4,399 \\
\hline 2900 & Refining & 1 & 101,000 & 87,560 & 102,847 \\
\hline 3000 & Rubber and plastics & 1 & 24,000 & 2,149 & 2,429 \\
\hline 3300 & Primary metal industries & 2 & 34,466 & 6,794 & 6,115 \\
\hline 3400 & Fabricated metal & 2 & 11,081 & 884 & 1,202 \\
\hline 3500 & $\begin{array}{l}\text { Industrial and commercial } \\
\text { machinery and computer equipment }\end{array}$ & 21 & 40,558 & 2,398 & 3,904 \\
\hline 3600 & Electronic equipment & 17 & 52,177 & 4,214 & 4,803 \\
\hline 3700 & Transportation equipment & 13 & 136,640 & 9,641 & 13,874 \\
\hline 3800 & $\begin{array}{l}\text { Measurement instruments and } \\
\text { photographic goods }\end{array}$ & 2 & 121,570 & 15,919 & 13,938 \\
\hline 4800 & Communications & 2 & 234,250 & 30,955 & 31,960 \\
\hline 5000 & Durable goods-wholesale & 1 & 1,700 & 189 & 399 \\
\hline Total & & 74 & 65,552 & 6,716 & 8,264 \\
\hline
\end{tabular}

Note: ${ }^{a}$ For each firm, the data are for the year of adoption

The data from Table II show that the firms in the sample have not had success in reducing the WIP and finished goods inventories. This underscores that large companies (which constitute a majority in the sample) are likely to influence their suppliers, but may not have the agility and ability to improve their own internal processes. This could be due to a wide variety of reasons. Large organizations, due to their size, have an in-built inertia for change. The processes to influence the reduction in WIP and finished goods may be more complex and strategic in nature as compared to the processes to influence the reduction in raw material. Also, it is possible that the complexity of the processes in controlling the WIP and finished goods would increase with the size of the organization. To make an impact on the reduction in the WIP inventories, in particular, and finished goods inventories, to a certain extent, changes may have to be brought about in a strategic manner with regard to layout re-configuration with cellular manufacturing/group technology, adoption of setup time reduction technologies, and crosstraining of personnel as stated by earlier researchers (Ebrahimpour and Schonberger, 1984; Gargeya and Thompson, 1994; Sohal et al., 1993). This may take a long period of time. A threeyear post-implementation time period may not be a sufficient enough duration to bring about substantial changes in the reduction of WIP inventories. 


\begin{tabular}{lcccc}
\hline $\begin{array}{l}\text { Table II } \\
\text { Inventory to sales ratios prior- and post-adoption of JIT production systems }\end{array}$ \\
\hline & $\begin{array}{c}\text { Average in } \\
\text { Years 1 and 2 }\end{array}$ & $\begin{array}{c}\text { Average in } \\
\text { Years 6 and 7 }\end{array}$ & $p$ value \\
\hline Total inventory to sales ratio & 0.1781 & 0.1474 & $0.0000^{*}$ \\
Raw materials inventory to sales ratio & 0.0591 & 0.4370 & $0.0000^{*}$ \\
Work-in-Process inventory to sales ratio & 0.0557 & 0.0484 & 0.0976 \\
Finished goods inventory to sales ratio & 0.0819 & 0.0728 & 0.0141
\end{tabular}

Notes: Year 4 is the adoption year for Just-in-Time product; "The difference in inventory to sales ratio is statistically significant at the 0.01 level

In general, the current research confirms the findings of Balakrishnan et al. (1996), Billesbach and Hayen (1994), and Huson and Nanda (1995) using a larger sample of firms (74 as compared to $46,28,55$, respectively) in 15 different industries (spread across four one-digit SIC codes). The data (which includes total inventory, raw material inventory, WIP inventory, and finished goods inventory) covers a longer time span (1975 to 1995) than previous studies.

Further research needs to be done on whether the results were more oriented to particular industries. Also, more work needs to be done on whether the timing (year) of the adoption of the JIT production system had any bearing on the reductions/non-reductions on inventory levels. Future investigations should focus on studying the impact of JIT adoption on inventories in the entire supply network (including inventories at the firm's suppliers' and customers' premises).

\section{References}

1. Balakrishnan, R., Linsmeier, T.J. and Venkatachalam, M. (1996), "Financial benefits from JIT adoption: effects of customer concentration and cost structure", The Accounting Review, Vol. 71 No. 2, pp. 183-205.

2. Billesbach, T.J. (1991), "A study of the implementation of just-in-time in the United States", Production and Inventory Management Journal, Vol. 32 No. 3, pp. 1-4.

3. Billesbach, T.J. and Hayen, R. (1994), "Long-term impact of just-in-time on inventory performance measures", Production and Inventory Management Journal, Vol. 35 No. 1, pp. 626.

4. Canel, C., Rosen, D. and Anderson, E.A. (2000), "Just-in-time is not just for manufacturing: a service perspective”, Industrial Management \& Data Systems, Vol. 100 Nos 1-2, pp. 51-60.

5. Chin, L. and Rafuse, B.A. (1993), “A small manufacturer adds JIT techniques to MRP”, Production and Inventory Management, Vol. 34 No. 4, pp. 18-21.

6. Cook, R.L. and Rogowski, R.A. (1996), “Applying JIT principles to continuous process manufacturing supply chains", Production and Inventory Management Journal, Vol. 37 No. 1, pp. 12-17. 
7. Crawford, K.M., Blackstone, J.H. and Cox, J.F. (1988), “A study of JIT implementation and operating problems", International Journal of Production Research, Vol. 26 No. 9, pp. 1561-8.

8. Deshpande, S.P. and Golhar, D.Y. (1995), "HRM practices in unionized and non-unionized Canadian JIT manufacturing firms", Production and Inventory Management Journal, Vol. 36 No. 1, pp. 15-19.

9. Ebrahimpour, M. and Schonberger, R.J. (1984), “The Japanese just-in-time/total quality control production system: potential for developing countries", International Journal of Production Research, Vol. 22 No. 3, pp. 421-30.

10. Gargeya, V.B. and Thompson, J.P. (1994), “Just-in-time production in small job shops”, Industrial Management, July/August, pp. 23-6.

11. Golhar, D.Y., Stamm, C.L. and Smith, W.P. (1990), “JIT implementation in manufacturing firms",Production and Inventory Management Journal, Vol. 31 No. 2, pp. 44-8.

12. Handfield, R. (1993), "Distinguishing features of just-in-time systems in the make-toorder/assemble-to-order environment", Decision Sciences, Vol. 24 No. 3, pp. 581-602.

13. Harber, D., Samson, D.A., Sohal, A.S. and Wirth, A. (1990), “Just-in-time: the issue of implementation",International Journal of Operations \& Production Management, Vol. 10 No. 1, pp. 21-30.

14. Hobbs, O.K. (1994), "Application of JIT techniques in a discrete batch job shop", Production and Inventory Management Journal, Vol. 35 No. 1, pp. 43-7.

15. Howton, S.D., Higgins, E.J. and Biggart, T.B. (2000), "The information content of just-intime inventory system adoption announcement", Journal of Business Finance \& Accounting, Vol. 27 No. 5-6, pp.711-33.

16. Huson, M., and Nanda, D. (1995), "The impact of just-in-time manufacturing on firm performance in the US", Journal of Operations Management, Vol. 12, pp. 297-310.

17. Im, J.H., and Lee, S.M. (1989), "Implementation of just-in-time systems in US manufacturing firms",International Journal of Operations \& Production Management, Vol. 9 No. 1, pp. 5-14.

18. Inman, R.A. and Mehra, S. (1990), "The transferability of just-in-time concepts to American small businesses", Interfaces, Vol. 20 No. 2, pp. 30-7.

19. Inman, R.A. and Mehra, S. (1993), "Financial justification of JIT implementation", International Journal of Operations \& Production Management, Vol. 13 No. 4, pp. 32-9. 
20. Lawrence, J.J., and Hottenstein, M.P. (1995), "The relationship between JIT manufacturing and performance in Mexican plants affiliated with US companies", Journal of Operations Management, Vol. 13, pp. 3-18.

21. Moras, R.G., and Dieck, A.J. (1992), “Industrial applications of just-in-time: lessons to be learned',Production and Inventory Management Journal, Vol. 33 No. 3, pp. 25-9.

22. Payne, T.E. (1993), “Acme manufacturing: a case study in JIT implementation”, Production and Inventory Management Journal, Vol. 34 No. 2, pp. 82-6.

23. Pelagagge, P.M. (1997), "Advanced manufacturing systems for automotive components production”,Industrial Management \& Data Systems, Vol. 97 No. 7-8, pp. 327-45.

24. Schonberger, R.J. (1986), World Class Manufacturing, The Free Press, New York, NY.

25. Sohal, A.S., Ramsay, L. and Samson, D. (1993), "JIT manufacturing: industry analysis and a methodology for implementation”, International Journal of Operations \& Production Management, Vol. 13 No. 7, pp. 22-56.

26. Sriparavastu, L. and Gupta, T. (1997), "An empirical study of just-in-time and total quality management principles implementation in manufacturing firms in the USA", International Journal of Operations \& Production Management, Vol. 17 Nos 11-12, pp. 1215-33.

27. Stamm, C.L. and Golhar, D.Y. (1991), “Customer and supplier linkages for small JIT manufacturing firms",Journal of Small Business Management, Vol. 29, July, pp. 43-9.

28. Temponi, C., and Pandya, S.Y. (1995), "Implementation of two JIT elements in small-sized manufacturing firms", Production and Inventory Management Journal, Vol. 36 No. 3, pp. 23-9.

29. Vergin, R.C. (1988), "An examination of inventory turnover in the Fortune 500 industrial companies",Production and Inventory Management Journal, Vol. 39 No. 1, pp. 51-6.

30. White, R.E. (1993), "An empirical assessment of JIT in US manufacturers", Production and Inventory Management Journal, Vol. 34 No. 2, pp. 38-42.

31. White, R.E., Pearson, J.N. and Wilson, J.R. (1999), “JIT manufacturing: a survey of implementations in small and large US manufacturers", Management Science, Vol. 45 No. 1, pp. 1-15.

32. Yasin, M.M., Small, M. and Wafa, M.A. (1997), "An empirical investigation of JIT effectiveness: an organizational perspective", Omega, Vol. 25 No. 4, pp. 461-71 